\title{
EFFECT OF SOWING DATES, HILL SPACING AND POTASSIUM FERTILIZATION ON YIELD, YIELD COMPONENS AND QUALITY OF SUGAR BEET (Beta vulgaris, L.) UNDER EL-MINIA GOVERNORATE CONDITIONS \\ Esmail A.A* and A.S. Abo El-Hamd** \\ * Dept. Environ., Fac. of Agric. El-Minia University. **Dept. Agron., Fac.of Agric., AL-Azhar Univ., Assiut.
}

\begin{abstract}
Two field experiments were carried out at the experimental farm of El-Minia University during 2003/2004 and 2004/2005 seasons to study the effect of sowing dates $\left(20^{\text {th }}\right.$ Sep., $10^{\text {th }}$ Oct. and $1^{\text {st }}$ Nov.), hill spacing $(15,20$ and $25 \mathrm{~cm}$.) and Potassium-rates $(0,24$ and $48 \mathrm{~kg} \mathrm{K2O} / \mathrm{fad}$.) as well as their interactions on yield, yield components and quality of sugar beet, c.v. Raspoly. The experimental design was split-split plot with three replications

The main results could be summarized as follows. All characters for yield and its components and quality were significantly affected by sowing dates. Sowing beet plants on $10^{\text {th }}$ Oct. gave the greatest values of root length, root diameter, root fresh weight, foliage fresh weight/plant, yields of root, top and sugar. as well as TSS\% and sucrose\% in both seasons, while purity \% recorded adversely trend in both seasons. Sowing beet plants on $1^{\text {st }}$ Nov. Produced the lowest averages from all traits, except purity $\%$ in the second season, while sowing beet plants on $20^{\text {th }}$ Sept. gave the highest average of purity \% in the first season and vice-versa in the second one.

Hill spacing of $20 \mathrm{~cm}$. gave the highest value of root length and diameter, foliage fresh weight, yields $f$ top, root and sugar as well as TSS $\%$ and sucrose $\%$ in both seasons, while purity \% resulted the lowest one in both seasons. On the other hand hill spacing of $15 \mathrm{~cm}$. between beet plants produced the lowest averages from this traits in both seasons, except root yield/ fad and TSS \% where the lowest values from this traits resulted from hill spacing of $25 \mathrm{~cm}$. between plants the greatest values of root fresh weight as well as juice purity \% obtained from $25 \mathrm{~cm}$. between hills in both seasons.

All characters significantly increased with increasing Potassium rate up to 48 $\mathrm{kg} \mathrm{K} \mathrm{K}_{2} \mathrm{O} / \mathrm{fad}$ except purity \% in the two seasons.

The interactions indicated that the highest yield from root and sugar /fad was obtained by sowing beet on $10^{\text {th }}$ Oct. at $20^{\text {th }} \mathrm{cm}$ between hills with $48 \mathrm{~kg} \mathrm{k} \mathrm{k}_{2} \mathrm{O} / \mathrm{fad}$.
\end{abstract}

\section{INTRODUCTION}

Sugar beet is one of the two crops (the other being sugar cane), which represent the important source of sucrose product. The importance of sugar beet crop to agriculture is not only confined to sugar production, but also it well known to be adopted to poor, saline, alkaline and calcareous soil.

The economic way of increasing sugar productivity could be achieved through developing appropriate new technology package for sugar beet crop that includes agronomic management to the yield and quality of sugar beet. This could be achieved through using the best cultivars and adapting cultural practices for this important crop for sugar production such as planting date, 


\section{Esmail A.A. and A.S. Abo El-Hamd}

density of planting, fertilization ...etc. (Moursy and Taha (1986), Mokadem (1999), EL-Harriri and Gobrah (2001) and Kandil, et al. (2002).

Ghandora (1994), Badawi, et al. (1995), and Metwally (1998) found that sowing sugar beet during October markedly increased root length and diameter, root weight, sugar content as well as root and sugar yields than sowing during November. Mokadem (1999) found that root and suger yield as well as sucrose $\%$ were significantly affected by sowing date. Abo salama and EL-Sayed (2000), Hassanin (2001), Kandil, et al. (2002) and Seadh (2004) found that planting sugar beet on $1^{\text {st }}$ Oct. gave significantly the greatest values of root length and diameter as well as root, top and sugar yield/ fad. Mohamed (2005) and Saad (2005) Mentioned that planting date of $1^{\text {st }}$ Oct. resulted the highest root length, root diameter, foliage fresh weight/ plant, top yield /fad, Sucrose \% and Purity \%, while planting date of $15^{\text {th }}$ Sept. produced the heaviest root fresh weight/plant, root and sugar yield as well as TSS \% in both seasons.

Several experiments have been carried out to determine the best plant density to give the highest production. Taha, et al. (1991) reported that the $25 \mathrm{~cm}$ spacing gave the greatest root yield/plant, while $20 \mathrm{~cm}$ spacing produced the highest yield of top and root/fad. Abd Alla, et al. (1995) found that the top yield/fad was significantly decreased with increasing plant density. Yonts and Smith (1997) stated that sugar beet grown in $56 \mathrm{~cm}$ row width corresponded with the higher sugar yield than sugar beet grown in the wother row width $(35,76$ and $97 \mathrm{~cm})$. Gobrah (2001) reported that the greatest root yield and recoverable sugar yield were obtained from plants planting at $20 \mathrm{~cm}$ between hills, while $15 \mathrm{~cm}$ between hills gave the highest top yield. Abo El- Wafa (2002) stated that increasing plant spacing from 20 to $30 \mathrm{~cm}$ between hills increased root and sugar yields. Ali (2005) reported that all growth characters significantly affected by planting spaces in both seasons. $10 \mathrm{~cm}$ hill spacing gave the tallest roots and greatest values of TSS $\%$, while $25 \mathrm{~cm}$ hill spacing produced the highest values of root diameter, root fresh weight /plant and foliage fresh weight/plant and added that hill spacing $20 \mathrm{~cm}$ resulted the highest averages of root, top and sugar yields /fad as well as juice purity \%. Abo-Bakr (2005) found that $15 \mathrm{~cm}$ hill spacing gave the greatest averages of root length as well as root and top yields/fad, while 20 $\mathrm{cm}$ hill spacing resulted the heaviest sugar yield /fad as well as TSS $\%$ and sucrose \% and added that $25 \mathrm{~cm}$ hill spacing gave the highest values of root diameter and root fresh weight /plant.

Potassium plays a found mental role in sucrose synthesis and storage. The influence of potassium is not only on carbohydrates assimilation but also in nitrogen metabolism (Pardo and Guadali (1993) and Seif (2000) Abd EL-Rahman (1996), Ibrahim (1998), EL-Shafaie(2000), Gobrah (2001), Hassanin (2001), Mahmoud (2004), Ahmed (2005) and Saad (2005) mentioned that root length, root diameter, root fresh weight/ plant, foliage fresh weight /plant, root, top and sugar yields/ fad. as well as sucrose and TSS percentages significantly increased with increasing potassium level up to $48 \mathrm{~kg} / \mathrm{k}_{20} / \mathrm{fad}$. On the other hand EL-Tweel (1999) found that there was significant decrease in top and sugar yields by increasing potassium levels from 0 to $48 \mathrm{~kg} \mathrm{~K} \mathrm{~K}_{2} \mathrm{O}$. and added that sucrose and purity percentages were not 
significantly affected by potassium rates. Mean while Thalooth, et al. (2001) and Omer, et al. (2002) showed that increasing k rate up to 72 or $96 \mathrm{kgk}_{2} \mathrm{O}$ /fad significantly increased root and sugar yields /fad as well as sucrose $\%$.

Therefore this investigation was designed to study the effect of sowing date, hill spacing and Potassium fertilization on yield and quality of sugar beet under El-Minia Governorate conditions.

\section{MATERIALS AND METHODS}

Two field experiments were carried out in 2003/2004 and 2004/2005 at the experimental farm of EL-Minia University to investigate the effect of sowing dates, hill spacing, potassium fertilization and their interactions on yield and quality of sugar beet (Beta vulgaris, L) Cultivar Ras poly.

Maize (Zea mays L.) was the preceding crop for the two seasons, phosphorus was applied as calcium super phosphate $15.5 \% \mathrm{P}_{2} \mathrm{O}_{5}(15 \mathrm{~kg}$ $\mathrm{P}_{2} \mathrm{O}_{5}$ ) during land preparation in both seasons. The texture of soil of the experiment sites was silt clay loam having silt 31.06 , clay 41.41 , sand 27.53 , total N $0.08 \%$, organic matter $1.52 \%$, PH 8.01, available P (ppm) 14.32, exch K (meq/100gm) 1.97.

The experimental design was split-split plot with three replications. The sowing dates i.e $20^{\text {th }}$ Sept, $10^{\text {th }}$ Oct and $1^{\text {st }}$ Nov were occupied the main plots. Sugar beet seeds were sown at 15, 20 and $25 \mathrm{~cm}$ apart in the sub plots. Potassium was applied after 30 days from sowing at rates of zero, 24 and $48 \mathrm{~kg} \mathrm{k} \mathrm{K}_{2} / \mathrm{fad}$ in the sub-sub plot consisted of 6 ridges, $55 \mathrm{~cm}$ between ridages and $3 \mathrm{~m}$ long (plot area $9.9 \mathrm{~m}^{2}$ ). Plants were thinned to one plant/hill after 30 days, Nitrogen fertilization $(80 \mathrm{kgN} / \mathrm{fad})$ was applied in the form of ammonium nitrate $33.5 \% \mathrm{~N}$ in two equal doses, the first after 30 days from sowing and the second at 50 days from sowing.

At harvest (195 days after sowing) five plants were chosen at random from the outer ridges of each sub-sub plot to estimate yield components and quality characters as follows:

$\begin{array}{ll}\text { 1. Root length }(\mathrm{cm}) \text {. } & \text { 2. Root diameter }(\mathrm{cm}) \text {. }\end{array}$

3. Root fresh weight/plant (gm). 4. Foliage fresh weight/plant (gm).

5. Total soluble solids (TSS\%) of roots, it was measured in juice of fresh root using hand refractometer.

6. Sucrose \%, it was determined according to A.O.A.C (1995).

7. Juice purity \%, it was calculated according to Sapronova, et al. (1972) using the following equation:-

$$
\text { Juice purity } \%=\frac{\text { Sucrose } \%}{\text { TSS } \%} \times 100
$$

At harvest sugar beet plants from the two inner ridges of each subsub plot were collected, roots and tops were separated and weight in $\mathrm{kg}$, then converted to estimate:-

1. Root yield (ton/fad).

2. Top yield (ton/fad).

3. Sugar yield (ton/fad). It was computed according to the following formula 


$$
\text { Sugar yield }=\frac{\text { Recovery sugar } x \text { root yield }}{100}
$$

- Recovery sugar $=\mathrm{S}-0.4(\mathrm{~B}-\mathrm{S}) \times 0.73$

- Where $\mathrm{S}=$ sucrose $\%, \mathrm{~B}=\mathrm{TSS} \%$

Data in each season were statistically analyzed according to Snedecor and Cochran (1967) for the comparison between means using the least significant differences (LSD) at the $5 \%$ probability.

\section{RESULTS AND DISCUSSION}

\section{A-Effect of sowing dates:}

Data recorded in Tables 1 and 2 indicated that sowing beet on $10^{\text {th }}$ of October was accompanied by a significant increase in all characters of yield components as well as yield and quality in both seasons except juice purity \% in both seasons. Sowing data of Oct. gave the tallest roots (35.54 and 38.63 $\mathrm{cm})$, thickest roots $(13.41$ and $14.71 \mathrm{~cm})$, heaviest root fresh weight $(693.38$ and $814.29 \mathrm{gm})$, heaviest foliage fresh weight/plant $(214.06$ and $231.28 \mathrm{gm})$, highest root yield /fad (25.53 and 26.69 ton), maximum top yield/fad (7.92 and 7.54 ton), highest sugar yield/fad (4.17and4.45 ton), maximum TSS\%(19.30 and 20.28\%) and highest sucrose \%(16.26 and 16.66) in the first and second seasons, respectively. Meanwhile purity \% took adversely trend in first season and recorded a medium values in the second season. On the contrary sowing beet plants on the $1^{\text {st }}$ Nov. resulted in the lowest averages from these characters, except purity \% in both seasons and sucrose $\%$ in the second season, where planting date of $1^{\text {st }}$ November produced the maximum average for purity \% in the second season and recorded a second rank for purity \% and sucrose \% in the first and second seasons, respectively. On the other hand sowing date on $20^{\text {th }}$ Sept. resulted in the highest value for purity \% in the first season and lowest one in the second season. The superiority of Oct. sowing may be due to the suitable environmental conditions during this period such as day length, relative humidity, temperature, light intensity and longer growth period which play a vital role in activating growth and formotion more photosynthates products, translocation and accumulation carbohydrates and sucrose. Consequently increasing dry matter accumulation as well as root weight, root and sugar yield/fad. These results are in accordance with those obtained by Mokadem (1999), Hassanin (2001) and Seadh (2004).

\section{B- Effect of hill spacing:}

Data illustrated in Tables 1 and 2 showed that all estimated characters were significantly affected by hill spacing in both seasons. Hill spacing of $20 \mathrm{~cm}$ between beet plants produced the highest means from root length, root diameter, foliage fresh weight per plant, root, top and sugar yield/fad. as well as TSS \% and sucrose $\%$ in both seasons, but purity $\%$ took adversely trend in the two growing seasons. 
J. Agric. Sci. Mansoura Univ., 32 (3), march, 2007 
Esmail A.A. and A.S. Abo El-Hamd 
On the other hand, hill spacing of $25 \mathrm{~cm}$ between beet plants gave the lowest averages from root and sugar yield/fad. as well as TSS \% in both seasons, mean while it gave the highest values for root fresh weight as well as purity \% in both seasons. The distance of $15 \mathrm{~cm}$. between beet plants produced the lowest averages from root length and diameter, root fresh weight, foliage fresh weight /plant, top yield/fad and sucrose \%, this was true in both seasons. The distance of $20 \mathrm{~cm}$ between beet plants out yielded the other hill spacing $(25$ and $15 \mathrm{~cm})$ in root yield/fad by 1.93 and 3.61 ton in the first season and 2.26 and 3.57 ton in the second season. Such increase in root yield may be due to the reduction in the competition between beet plants for growth elements i.e nutrients, water and light which cause an increase in leaf area which it affects the amount of radiation percentage and reaching to all leaves reflected the increase in root yield per unit area. Also hill spacing of 20 $\mathrm{cm}$ surpassed the other hill spacing (25 and 15) in sugar yield/fad by 0.62 and 0.83 ton in the first season and by 0.56 and 0.73 ton in the second season. This increase may be due to the superior of $20 \mathrm{~cm}$ hill spacing in root yield and sucrose \%. Similar results were obtained by Nassar (2001), Abo EL-Wafa (2002), Cakmakci and oral (2002) ,Omar et al (2002).

\section{Effect of Potassium fertilization:}

Data presented in Tables 1 and 2 revealed that all characters of yield and quality were significantly affected by Potassium-rates in both seasons. A gradual increase in root length, root diameter, root fresh weight, foliage fresh weight per plant, root, top and sugar yields/fad as well as TSS \% and sucrose $\%$ increased as $\mathrm{K}$ - rate raised from 0 to $48 \mathrm{~kg} \mathrm{~K} \mathrm{~K}_{2} \mathrm{O} / \mathrm{fad}$, this was true in both season. On the other hand, purity \% increased with no significance differences as $\mathrm{K}$ - rate raised from 0 to $24 \mathrm{~kg} \mathrm{~K} 2 \mathrm{O} / \mathrm{fad}$ in the first season, but purity \% decreased significantly by increasing K- rate to $48 \mathrm{~kg} \mathrm{~K} 2 \mathrm{O} / \mathrm{fad}$ in both seasons. Such increase in root yield/fad mounted to 0.75 and 1.51 ton/fad in the first season, being 0.68 and 1.31 ton/fad in the second season, as K-rate raised from 0 to 24 and $48 \mathrm{~kg} \mathrm{~K} 2 \mathrm{O} / \mathrm{fad}$. Similar significant increases in sugar yield/fad amounted to 0.21 and 0.40 ton in the first season, being 0.20 and 0.35 ton in the second season. These results could be attributed to the important role of potassium in physiological process in plant such as translocation of sugar and carbohydrates of assimilates from the top to the under ground part (root). (Tisdal and Nelson 1985) Also its role in nutritional balance, which increase organic compounds through phytosynthesis (ELHarriri and Gobrh 2001). These results are in harmony with those obtained by EL-moursy et al. (1998), Seif (2000), Hassanin (2001) and Ahmed (2005).

\section{Effect of interaction:}

I. A significant interaction between sowing dates and hill spacing was found on all traits in both seasons except root diameter in the first season. The treatment of $20 \mathrm{~cm}$ between beet plants and sown on $10^{\text {th }}$ Oct. produced the highest averages from all characters in both seasons, except root fresh weight which gave the highest means from sowing on $10^{\text {th }}$ Oct $\times 25$ $\mathrm{cm}$ between hills in both seasons as well as juice purity \% which resulted the highest values from planting on $20^{\text {th }}$ Sept $\times 25 \mathrm{~cm}$ between hills in the first season and sowing on $1^{\text {st }}$ Nov $x$ planting at $25 \mathrm{~cm}$ between hills in the second season (Table 3). 
Table (3): The obtained significant interaction effect of sowing dates $x$ hill spacing during the two seasons

\begin{tabular}{|c|c|c|}
\hline Characters & Treatments & $\begin{array}{c}\text { Highest } \\
\text { values }\end{array}$ \\
\hline \multicolumn{3}{|l|}{ 2003/2004 season } \\
\hline Root length (cm) & Sowing on $10^{\text {th }}$ Oct. $x$ planting at $20 \mathrm{~cm}$ between hills & 36.78 \\
\hline Root fresh w & Sowing on $10^{\text {th }}$ Oct. $x$ pla & 748.93 \\
\hline Foliage fres & Sowing on $10^{\text {th }}$ Oct. $x$ planting at $20 \mathrm{~cm}$ between hills & 237.38 \\
\hline Root yield ( & Sowing on $10^{\text {th }}$ Oct. $x$ planting at $20 \mathrm{~cm}$ between hills & 27.51 \\
\hline Top yield $(\mathrm{t}$ & Sowing on $10^{\text {th }}$ Oct. $x$ plantin & 10.40 \\
\hline yield $(\mathrm{t}$ & $10^{\text {th }}$ Oct. $x$ plar & 4.76 \\
\hline TSS & th Oct. $x$ & 20.94 \\
\hline Sucro & )$^{\text {th }}$ Oct. $x$ & 17.28 \\
\hline Puri & $0^{\text {th }}$ Sept. $x$ & 88.62 \\
\hline \multicolumn{3}{|l|}{ 2004/2005 season } \\
\hline Root I & $10^{\text {th }}$ Oct. $x$ & 40.36 \\
\hline Roo & th Oct. $x$ & 15.51 \\
\hline Root fresh & $10^{\text {th }}$ Oct. $x$ & 882.73 \\
\hline Folia & $10^{\text {th }}$ Oct. $x$ & 247.30 \\
\hline Root y & at $20 \mathrm{~cm}$ between hills & 28.96 \\
\hline Top yield $(\mathrm{t}$ & on $10^{\text {th }}$ Oct. $x$ planting at $20 \mathrm{~cm}$ between hills & 9.38 \\
\hline Sugar yield (ton/fad) & $10^{\text {th }}$ Oct. $x$ pl & 5.01 \\
\hline TSS \% & Sowing on $10^{\text {th }}$ Oct. $x$ pl & 22.02 \\
\hline se $\%$ & on $10^{\text {th }}$ Oct. $x$ pl & 17.42 \\
\hline Purity \% & Sowing on $1^{\text {st }}$ Nov. $x$ planting at $25 \mathrm{~cm}$ between hills & 86.01 \\
\hline
\end{tabular}

II. The interaction between sowing dates $\mathrm{x}$ K-rates had a significant effect on root fresh weight and TSS \% in both season as well as purity \% in the first season and top yield /fad in the second season. Sowing beet plants on $10^{\text {th }}$ with $48 \mathrm{~kg} \mathrm{~K} 2 \mathrm{O} / \mathrm{fad}$ gave the highest values for this trait except purity $\%$, where sowing on $20^{\text {th }}$ Sept with $24 \mathrm{~kg} \mathrm{~K}_{2} \mathrm{O} / \mathrm{fad}$ resulted in the maximum mean in the first season (Table 4).

III. Concerning the interaction between hill spacing $x$ K-rates, significant effects were obtained on sugar yield/fad, TSS $\%$ and sucrose $\%$ in both seasons as well as foliage fresh weight/plant, root yield/fad and purity \% in the first season and top yield/fad in the second season. Hill spacing of $20 \mathrm{~cm}$ with $48 \mathrm{~kg} \mathrm{~K} \mathrm{~K}_{2} \mathrm{O}$ produced the greatest values for this characters except purity \% where hill spacing $25 \mathrm{~cm}$ with zero K-rate resulted the highest one in the first season (Table 5).

IV. The interaction among the three factors under studies significantly affected root fresh weight in both seasons as well as foliage fresh weight/plant, root yield/fad, sugar yield/fad and sucrose percentage in the first season and TSS \% in the second season. The highest averages from these traits resulted by sowing beet plants on $10^{\text {th }}$ Oct at hill spacing 20 $\mathrm{cm}$ between hills with $48 \mathrm{~kg} \mathrm{~K} \mathrm{~K}_{2} \mathrm{O}$ (Table 6).

VI. Finally, it could be concluded that under the condition of this study the highest root and sugar yields/fad produced by sowing beet on $10^{\text {th }}$ Oct at $20 \mathrm{~cm}$ between hills with $48 \mathrm{~kg} \mathrm{~K} \mathrm{~K}_{2} \mathrm{O} / \mathrm{fad}$. 
Table (4):The obtained significant interaction effect of sowing date $\times \mathrm{K}$ rates during the two seasons.

\begin{tabular}{|c|c|c|}
\hline Characters & Treatments & $\begin{array}{c}\text { Highest } \\
\text { values }\end{array}$ \\
\hline \multicolumn{3}{|l|}{$2003 / 2004$ season } \\
\hline $\begin{array}{l}\text { Root fresh weight }(\mathrm{gm}) \\
\text { TSS \% } \\
\text { Purity \% }\end{array}$ & $\begin{array}{l}\text { Sowing on } 10^{\text {th }} \text { Oct. with } 48 \mathrm{~kg} \mathrm{~K} \mathrm{O} / \mathrm{fad} \text {. } \\
\text { Sowing on } 10^{\text {th }} \text { Oct. with } 48 \mathrm{~kg} \mathrm{~K} \mathrm{~K}_{2} \mathrm{O} / \mathrm{fad} \text {. } \\
\text { Sowing on } 20^{\text {th }} \text { Sept. with } 24 \mathrm{~kg} \mathrm{~K} \mathrm{~K}_{2} \mathrm{O} / \mathrm{fad} \text {. }\end{array}$ & $\begin{array}{c}708.64 \\
19.80 \\
86.88\end{array}$ \\
\hline \multicolumn{3}{|l|}{$2004 / 2005$ season } \\
\hline $\begin{array}{l}\text { Root fresh weight (gm) } \\
\text { TSS \% } \\
\text { Top yield (ton/fad) } \\
\end{array}$ & $\begin{array}{l}\text { Sowing on } 10^{\text {th }} \text { Oct. with } 48 \mathrm{~kg} \mathrm{~K} \mathrm{O} / \mathrm{fad} \text {. } \\
\text { Sowing on } 10^{\text {th }} \text { Oct. with } 48 \mathrm{~kg} \mathrm{~K} 2 \mathrm{O} / \mathrm{fad} \text {. } \\
\text { Sowing on } 10^{\text {th }} \text { Oct. with } 48 \mathrm{~kg} \mathrm{~K} \mathrm{~K}_{2} \mathrm{O} / \mathrm{fad} \text {. }\end{array}$ & $\begin{array}{c}834.70 \\
20.88 \\
7.88 \\
\end{array}$ \\
\hline
\end{tabular}

Table (5): The obtained significant interaction effect of hills pacing $x \mathrm{~K}$ rates during the two seasons.

\begin{tabular}{|c|c|c|}
\hline Characters & Treatments & $\begin{array}{c}\text { Highest } \\
\text { values }\end{array}$ \\
\hline \multicolumn{3}{|l|}{ 2003/2004season } \\
\hline Foliage fresh weight /plant (gm) & Hill spacing $20 \mathrm{~cm}$ with $48 \mathrm{~kg} \mathrm{k} \mathrm{O} / \mathrm{fad}$. & 227.74 \\
\hline Root yield (ton/fad) & Hill spacing $20 \mathrm{~cm}$ with $48 \mathrm{~kg} \mathrm{k} \mathrm{O} / \mathrm{fad}$. & 27.04 \\
\hline Sugar yield (ton/fad) & Hill spacing $20 \mathrm{~cm}$ with $48 \mathrm{~kg} \mathrm{k} \mathrm{O} / \mathrm{fad}$. & 4.65 \\
\hline TSS \% & Hill spacing $20 \mathrm{~cm}$ with $48 \mathrm{~kg} \mathrm{k} \mathrm{O} / \mathrm{fad}$. & 20.47 \\
\hline Sucrose \% & Hill spacing $20 \mathrm{~cm}$ with $48 \mathrm{~kg} \mathrm{k} \mathrm{O} / \mathrm{fad}$. & 17.20 \\
\hline Purity \% & Hill spacing $20 \mathrm{~cm}$ with $48 \mathrm{~kg} \mathrm{k} \mathrm{O} / \mathrm{fad}$. & 87.71 \\
\hline \multicolumn{3}{|l|}{ 2004/2005 season } \\
\hline Top yield (ton/fad) & Hill spacing $20 \mathrm{~cm}$ with $48 \mathrm{~kg} \mathrm{k} \mathrm{O} / \mathrm{fad}$. & 9.64 \\
\hline Sugar yield (ton/fad) & Hill spacing $20 \mathrm{~cm}$ with $48 \mathrm{~kg} \mathrm{k} \mathrm{O} / \mathrm{fad}$. & 4.72 \\
\hline TSS \% & Hill spacing $20 \mathrm{~cm}$ with $48 \mathrm{~kg} \mathrm{k} \mathrm{O} / \mathrm{fad}$. & 21.47 \\
\hline Sucrose \% & Hill spacing $20 \mathrm{~cm}$ with $48 \mathrm{~kg} \mathrm{k} \mathrm{O} / \mathrm{fad}$. & 16.88 \\
\hline
\end{tabular}

Table (6): The obtained significant interaction effect of sowing date $x$ hill spacing $\mathrm{x} \mathrm{K}$ rates during the two seasons.

\begin{tabular}{|c|c|c|}
\hline Characters & Treatments & $\begin{array}{l}\text { Highest } \\
\text { values }\end{array}$ \\
\hline \multicolumn{3}{|l|}{ 2003/2004 season } \\
\hline Root fresh weight (gm) & Sowing date $10^{\text {th }}$ Oct. at $20 \mathrm{~cm}$ with $48 \mathrm{~kg} \mathrm{~K}_{2} \mathrm{O} / \mathrm{fad}$. & 762.45 \\
\hline Foliage fresh weight (gm) & Sowing date $10^{\text {th }}$ Oct. at $20 \mathrm{~cm}$ with $48 \mathrm{~kg} \mathrm{~K} \mathrm{~K}_{2} \mathrm{O} / \mathrm{fad}$. & 248.30 \\
\hline Root yield (ton/fad) & Sowing date $10^{\text {th }}$ Oct. at $20 \mathrm{~cm}$ with $48 \mathrm{~kg} \mathrm{~K} \mathrm{~K}_{2} \mathrm{O} / \mathrm{fad}$. & 28.47 \\
\hline Sugar yield (ton/fad) & Sowing date $10^{\text {th }}$ Oct. at $20 \mathrm{~cm}$ with $48 \mathrm{~kg} \mathrm{~K} \mathrm{~K}_{2} \mathrm{O} / \mathrm{fad}$. & 5.10 \\
\hline Sucrose \% & Sowing date $10^{\text {th }}$ Oct. at $20 \mathrm{~cm}$ with $48 \mathrm{~kg} \mathrm{~K} 2 \mathrm{O} / \mathrm{fad}$. & 17.20 \\
\hline \multicolumn{3}{|l|}{ 2004/2005 season } \\
\hline Root fresh weight (gm) & Sowing on $10^{\text {th }}$ Oct. at $20 \mathrm{~cm}$ with $48 \mathrm{~kg} \mathrm{~K}_{2} \mathrm{O} / \mathrm{fad}$. & 909.00 \\
\hline TSS \% & Sowing on $10^{\text {th }}$ Oct. at $20 \mathrm{~cm}$ with $48 \mathrm{~kg} \mathrm{~K} \mathrm{~K}_{2} \mathrm{O} / \mathrm{fad}$. & 22.70 \\
\hline
\end{tabular}

\section{REFERENCES}

Abd -Alla, A.F; A.L. Allam; M.A.EL-Hawary and H.M.EL-Sayed (1995). Influence of plant densities on growth and yield of some sugar beet cultivates. Egypt. J. App.Sci.,10(9): 281-292.

Abd El-Rhman; M.M (1996). The effect of NP and K fertilization on growth, yield and some physiological characters of sugar beet (Beta vulgans, L.) M. Sc. Thesis Fac. of Agric. Zagazig Univ, Egypt. 
Abo Bakr; M.A.(2005). Influence of irrigation intervals, planting space and K level on yield and quality of sugar beet under EL-Minia conditions Ph.D. Thesis. Fac. of Agric. EL-Minia Univ., Egypt.

Abo-EL-Wafa; A.M.(2002). Effect of planting spaces nitrogen level and its frequency on yield and quality of kawmera sugar beet cultivar. J.Agric. Mansoura Univ., 27(2): 707:716.

Abo-Salama; A.M. and S.I.EL-Sayed (2000). Studies on some sugar beet cultivars under Middle Egypt condition. Response to planting and harvesting dates. Assiut, Sci. 31(1):137-158.

Ahmed, A.F.EL.(2005). Effect of Potassium, Magnesium and Boron on sugar beet yield and quality grown in the newly reclaimed soils. M.Sc. Thesis, Fac. of Agric. EL- Minia Univ., Egypt.

Ali, S. Abo. EL.M. (2005). Agricultural studies on sugar beet in newly reclaimed lands of Sohag Governorate M. Sc. Thesis Fac. of Agric. ELMinia Univ., Egypt.

A.O.A.C (1995). Official methods of analysis, Association of official Agric. Chemist Washington, D.C, USA.

Badawi, M. A. ; M. A. EL- Agroody and A. W. Attia (1995). Effect of planting dates and NPK fertilization on growth and yield of sugar beet. Agric. Sci. Mansoura Univ. 20(6): 2683-2689.

Cakmakic, R. and E. Oral (2002). Root yield quality of sugar beet in relation to plant population and harvesting dates interaction. Turkish. J. Agric. 26(3): 133-139.

El- Harriri, D. M.; and Gobarh, Mirvat G. (2001). Response of growth yield and quality of sugar beet to nitrogen and potassium fertilizers under newly reclaimed soils. J. Agric. Sci. Mansoura Univ., 26(10),: 58955907.

EL-Shafaei, A. M. A. (2000). Effect of nitrogen and potassium fertilization on yield and quality of sugar beet. Egypt. J. Agric. Res. 78(2): 759-767.

EL- Taweel, Fayza, M. A. (1999). Response of some sugar beet varieties to potassium and magnesium fertilizers Ph. D. Thesis Fac. of Agric. Zagazig Univ., Egypt.

EL-Moursy, S. A.; A.T. EL- Kassaby, A. M. Salam, and H.M. Sarhan (1998). Macroelements requirements of sugar beet. J. Agric. Sci. Mansoura Univ., 23(2): 701-710.

Ghandorah, M. O. (1994). Effect of sowing dates and cultivars on sugar beet (Beta Vulgaris, L) production in Central Region of Saudi- Arabian Arab Gulf J. Sci. Res. 12(3):465-478.

Gobrah, Mirvat G. (2001). Influence of plant densities and harvest dates on growth, yield and quality of sugar beet (Beta vulgaris, L.) under newly reclaimed soil. J. Agric. Mansoura Univ., 26(10) : 5909-5920.

Hassanin, M. A. (2001). Effect of hill spacing and potassium fertilization at two sowing dates on sugar beet yield and quality. Bull. Fac. Agric. Cairo Univ., 52:27-46.

Ibrahim, M.F.M. (1998). The effect of some fertilization element on yield and quality of sugar beet Ph.D. Thesis, Fac. of Agric. Zagazig Univ., Egypt. 
Kandil, A.A; M. A. Badawi; S.A. EL- Moursi and U.M.A. Abdou (2002 b). Effect of planting dates, nitrogen levels and biofertilization treatments on yield and quality of sugar beet. J.Agric. Sci. Mansoura Univ., 27(11):5258-5266.

Mahmoud, M. (2004). Effect of irrigation, $\mathrm{K}$ fertilization and crop relation on production of sugar beet in Beni-Suef Governorate. M. Sc. Thesis Fac. of Agric. EL-Minia Univ., Egypt.

Metwally, A.A.M. (1998). Effect of some agricultural practices on sugar beet (Beta Vulgaris, L) Ph.D. Thesis Fac. of Agric. EL-Minia Univ., Egypt.

Mohamed, Y.A.M. (2005). Studies on the effect of planting dates, planting spaces and nitrogen fertilization on yield and quality of sugar beet. M. Sc. Thesis Fac. of Agric. EL-Minia Univ., Egypt.

Mokadem, Sh.A. (1999). Effect of varying sowing dates on yield and quality of some sugar beet cultivars under Minia condition, Zagazig Univ. J. Agric. Res. 26(2):253-266.

Moursy, M. A.; and Taha E.M. (1986). Effect of boron, manganese and their combination on sugar beet under EL-Minia condition. Concentration and uptake of N.P.K and Mn. Annals Agric. Sci. Fac. Agric. Ain Shams Univ. Egypt 31(2):1241-1254.

Nassar, A. M.(2001). Effect of plant density on the productivity of some sugar beet varieties. J. Agric. Sci. Mansoura Univ. 26(12):7533-7546.

Omar, E. H.; Ghazy; M.A.A. Abd- Allah and M.M. Ragab (2002). Response of sugar beet to termination of last irrigation, hill spacing and potassium fertilization. J.Agric. Sci. Mansoura Univ. 27(6):4291-4302.

Pardo, M. T. and M. E. Guadalix (1993). Effect of nitrogen and potassium fertilization on yield, sucrose \% and juice purity of sugar beet. Potash Review. Subject 7, No 2/1493. Root and Tuber Crops $6^{\text {th }}$ Suite P.P. 1 7.

Saad, S.K.A (2005). Effect of some agricultural practices on sugar beet under newly reclaimed land. M.Sc. Thesis. Fac. of Agric.El-Minia Univ.,Egypt.

Sapronova, A. R., A.S. Joshman and N.A. Loseavo (1972). General technology of sugar and sugar substance pisch chevoges promysh connest pub. Moscow, 464.p

Seadh; S. EL. G. (2004). Agricultural studies on sugar beet crop Ph.D. Thesis Fac. of Agric. Mansoura Univ., Egypt.

Seif, Laila, M. A. (2000). The relative importance of potassium fertilizer for sugar beet under Upper Egypt condition. Minufya J. Agric. Res. 25(5):1215-1227.

Snedecor, G.W. and W.G. Cochran (1967). Statistical Methods $5^{\text {th }}$ Ed., lowa State Univ. Press Ames lowa USA. 593 P.

Taha, E.M.; M.S. Ashmoony; A.A EL- Sherbiny (1991). Influence of plant population, time of application and rate of N.K. fertilization on sugar beet. Minia J. Agric. Res. Dev. 13(6):953-965.

Thalooth, A. T. Nadia; M .A. Badr and A.A EL- Zeiny (2001). Effect of potassium fertilization and seed treatments with hesbiade on growth and yield of sugar beet under saline condition Egypt. J. App. Sci. 16(9):146-156. 


\section{Esmail A.A. and A.S. Abo El-Hamd}

Tisdal, S. I. And W.L. Nelson (1985). Soil fertility and fertilizers, Macmilla Foblishing Co. Inc. United States of America.

Yonts; C.D. and J.A Smith (1997). Effect of plant population and row width on yield of sugar beet, J. Sugar Beet Res. 34(1-2):21-30.

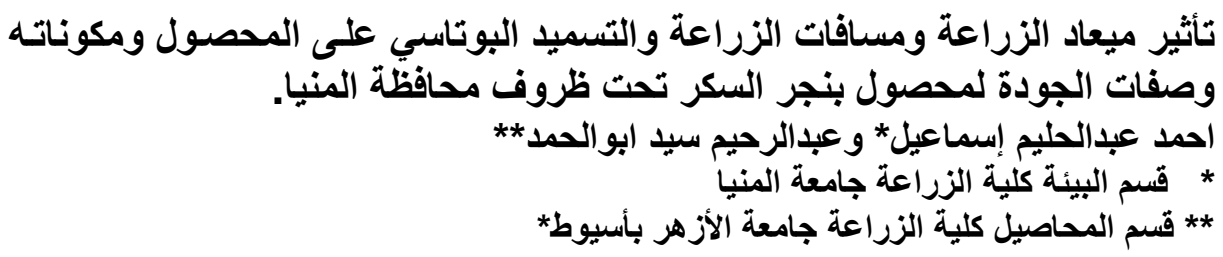

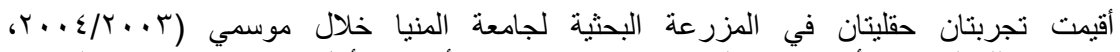

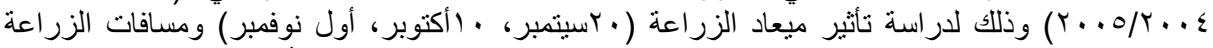

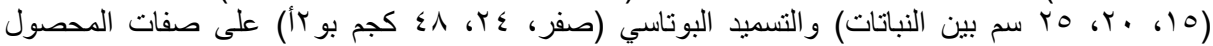
ومكوناتة وجودة محصول بنجر السكر صنف راس بولي وقد استخدم تصميم القطع المنشقة مرتين فى ثلاث

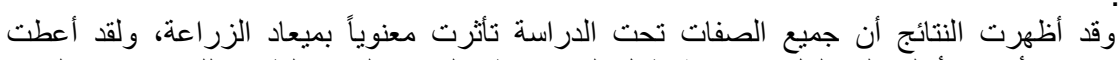
مكررات.

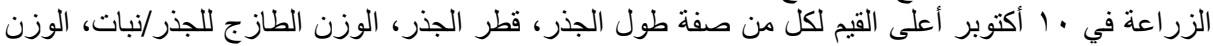

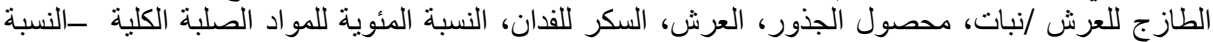

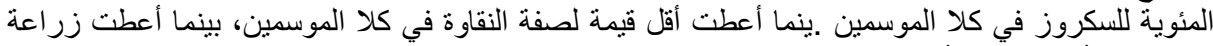

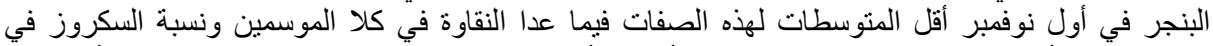

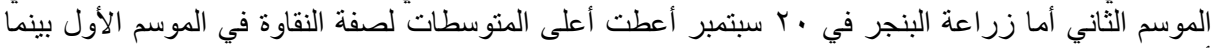

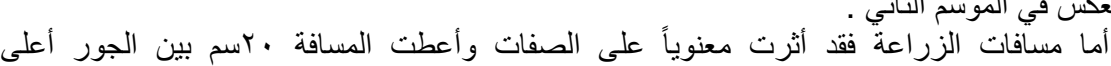

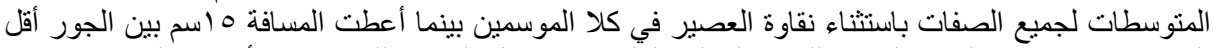

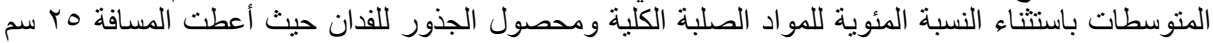

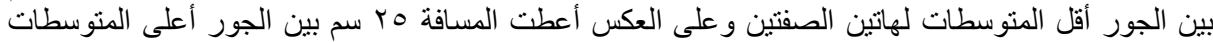

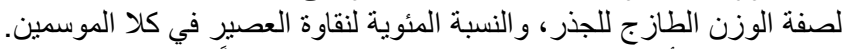

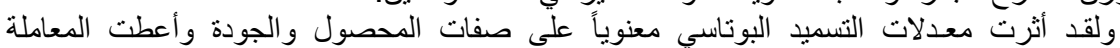

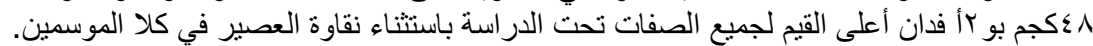

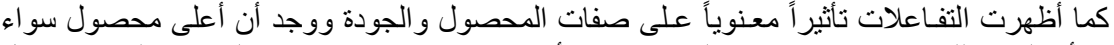

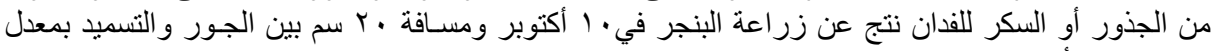

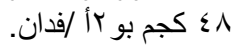


J. Agric. Sci. Mansoura Univ., 32 (3): 1627 - 1638, 2007

Table (1): Effect of sowing dates, hill spacing and potassium on root length, root diameter, root fresh weight, foliage fresh weight/plant and root yield/fad. of sugar beet in 2003/2004 and 2004/2005 seasons. .

\begin{tabular}{|c|c|c|c|c|c|c|c|c|c|c|}
\hline \multirow{2}{*}{\begin{tabular}{|c|} 
Characters \\
Treatments
\end{tabular}} & \multicolumn{2}{|c|}{ Root length (cm) } & \multicolumn{2}{|c|}{ Root diameter (cm) } & \multicolumn{2}{|c|}{$\begin{array}{c}\text { Root fresh weight } \\
(\mathrm{gm})\end{array}$} & \multicolumn{2}{|c|}{$\begin{array}{c}\begin{array}{c}\text { Foliage fresh } \\
\text { weight/plant (gm) }\end{array} \\
\end{array}$} & \multicolumn{2}{|c|}{ Root yield (ton/fad) } \\
\hline & $2003 / 2004$ & $2004 / 2005$ & $2003 / 2004$ & 2004/2005 & $2003 / 2004$ & $2004 / 2005$ & $2003 / 2004$ & $2004 / 2005$ & $2003 / 2004$ & 2004/2005 \\
\hline \multicolumn{11}{|l|}{ Sowing dates } \\
\hline $20^{\text {th }}$ Sept. & 32.66 & 36.65 & 11.25 & 12.77 & 669.91 & 750.63 & 208.33 & 210.65 & 24.69 & 25.43 \\
\hline $10^{\text {th }}$ Oct. & 35.54 & 38.63 & 13.41 & 14.71 & 693.38 & 814.29 & 214.06 & 231.28 & 25.53 & 26.69 \\
\hline $1^{\text {st }}$ Nov. & 30.89 & 34.37 & 10.36 & 11.59 & 561.75 & 688.15 & 199.64 & 203.44 & 23.15 & 24.64 \\
\hline L. S. D. .05 & 0.18 & 0.25 & 0.15 & 0.21 & 6.05 & 5.89 & 3.47 & 1.75 & 0.15 & 0.11 \\
\hline \multicolumn{11}{|l|}{ Hill spacing } \\
\hline 15 & 31.90 & 35.37 & 10.77 & 12.14 & 572.43 & 662.64 & 201.05 & 206.88 & 24.37 & 25.27 \\
\hline 20 & 34.35 & 37.90 & 12.55 & 13.70 & 667.10 & 760.01 & 217.14 & 223.66 & 26.30 & 27.53 \\
\hline 25 & 32.84 & 36.39 & 11.70 & 13.23 & 685.52 & 830.43 & 208.85 & 214.33 & 22.69 & 23.46 \\
\hline L. S. D. .05 & 0.14 & 0.16 & 0.21 & 0.18 & 5.36 & 5.38 & 2.26 & 1.27 & 0.08 & 0.12 \\
\hline \multicolumn{11}{|c|}{ Potassium levels $\mathrm{K}_{2} \mathrm{O} \mathrm{Kg} / \mathrm{fad}$} \\
\hline 0 & 32.07 & 35.59 & 10.82 & 12.29 & 623.43 & 730.44 & 199.11 & 205.36 & 23.70 & 24.92 \\
\hline 24 & 33.07 & 36.62 & 11.67 & 13.09 & 642.53 & 753.01 & 209.39 & 215.64 & 24.45 & 25.60 \\
\hline 48 & 33.95 & 37.44 & 12.52 & 13.69 & 659.09 & 769.62 & 218.58 & 224.37 & 25.21 & 26.23 \\
\hline L. S. D. . .05 & 0.16 & 0.12 & 0.17 & 0.50 & 2.17 & 3.82 & 1.12 & 0.35 & 0.10 & 0.21 \\
\hline
\end{tabular}




\section{Esmail A.A. and A.S. Abo El-Hamd}


J. Agric. Sci. Mansoura Univ., 32 (3): 1627 - 1638, 2007

Table (2): Effect of sowing dates, hill spacing and potassium levels on top yield / fad, sugar yield /fad, TSS \%, sucrose $\%$ and purity $\%$ of sugar beet in 2003/2004 and 2004/2005 seasons.

\begin{tabular}{|c|c|c|c|c|c|c|c|c|c|c|}
\hline \multirow{2}{*}{\begin{tabular}{|c|} 
Characters \\
Treatments \\
\end{tabular}} & \multicolumn{2}{|c|}{ Top yield (ton/fad) } & \multicolumn{2}{|c|}{ Sugar yield (ton/fad) } & \multicolumn{2}{|c|}{ TSS \% } & \multicolumn{2}{|c|}{ Sucrose \% } & \multicolumn{2}{|c|}{ Purity \% } \\
\hline & $2003 / 2004$ & $2004 / 2005$ & $2003 / 2004$ & $2004 / 2005$ & $2003 / 2004$ & $2004 / 2005$ & $2003 / 2004$ & $2004 / 2005$ & $2003 / 2004$ & $2004 / 2005$ \\
\hline \multicolumn{11}{|c|}{\begin{tabular}{|l|l|} 
Sowing dates \\
\end{tabular}} \\
\hline $20^{\text {th }}$ Sept. & 7.44 & 7.46 & 3.99 & 3.99 & 18.66 & 19.65 & 16.13 & 15.68 & 86.45 & 79.97 \\
\hline $10^{\text {th }}$ Oct. & 7.92 & 7.54 & 4.17 & 4.45 & 19.30 & 20.28 & 16.26 & 16.66 & 84.65 & 82.21 \\
\hline $1^{\text {st }}$ Nov. & 7.07 & 7.15 & 3.60 & 3.90 & 17.98 & 18.89 & 15.52 & 15.82 & 85.74 & 83.57 \\
\hline L. S. D. .05 & 0.13 & 0.08 & 0.02 & 0.04 & 0.11 & 0.20 & 0.11 & 0.13 & 1.15 & 0.60 \\
\hline \multicolumn{11}{|l|}{ Hill spacing } \\
\hline 15 & 5.96 & 6.17 & 3.78 & 3.98 & 18.26 & 19.30 & 15.49 & 15.69 & 85.17 & 81.45 \\
\hline 20 & 9.57 & 9.21 & 4.40 & 4.54 & 19.94 & 20.89 & 16.71 & 16.51 & 83.84 & 79.07 \\
\hline 25 & 6.91 & 6.78 & 3.57 & 3.81 & 17.74 & 18.63 & 15.70 & 15.95 & 87.83 & 85.24 \\
\hline L. S. D. .05 & 0.27 & 0.08 & 0.04 & 0.04 & 0.16 & 0.15 & 0.13 & 0.10 & 0.75 & 0.67 \\
\hline \multicolumn{11}{|c|}{ Potassium levels $\mathrm{K}_{2} \mathrm{O} \quad \mathrm{Kg} / \mathrm{fad}$. } \\
\hline 0 & 7.15 & 7.05 & 3.71 & 3.93 & 18.15 & 19.15 & 15.64 & 15.74 & 85.82 & 82.26 \\
\hline 24 & 7.48 & 7.41 & 3.92 & 4.13 & 18.61 & 19.58 & 15.98 & 16.09 & 86.13 & 82.23 \\
\hline 48 & 7.80 & 7.70 & 4.11 & 4.28 & 19.19 & 20.09 & 16.29 & 16.33 & 84.89 & 81.27 \\
\hline L. S. D. .05 & 0.43 & 0.03 & 0.02 & 0.03 & 0.10 & 0.11 & 0.08 & 0.10 & 0.78 & 0.11 \\
\hline
\end{tabular}

